Available online at: http://lumenpublishing.com/proceedings/.../rec-november-2017/

$18^{\text {th }}$ edition of the Conference "Risk in Contemporary Economy",

RCE2017, June 9-10, 2017, Galati, Romania

\title{
Risk in Contemporary Economy
}

\section{Impact of Globalization on the Romanian Labor Market}

\author{
Ramona Mariana CĂLINIC $\breve{A}$ \\ https://doi.org/10.18662/lumproc.rce2017.1.32
}

How to cite: Calinca, R. M. (2017). Impact of Globalization on the Romanian Labor Market. In S. Hugues, \& N. Cristache (eds.), Risk in Contemporary Economy (pp. 364-373). Iasi, Romania: LUMEN Proceedings. https://doi.org/10.18662/lumproc.rce2017.1.32

(C) The Authors, Faculty of Economics and Business Administration, Dunarea de Jos University from Galati, Romania \& LUMEN Proceedings. 


\title{
International Scientific Conference Risk in Contemporary Economy | RCE 2017 | 9-10 June 2017 | Galati - Romania
}

\section{Impact of Globalization on the Romanian Labor Market}

\author{
Ramona Mariana CĂLINIC $\breve{A}^{1}$
}

Abstract

Globalization has an important impact on the world economy, its influence being reflected in all areas of activity and changes in the labor market of many countries are quite spectacular. The purpose of this paper is to analyze the evolution of the labor market under globalization and to identify its impact on the Romanian labor market.

Keywords: globalization, labor market, migration

\section{Introduction}

In recent years, the economies of European countries and the Romanian economy have been affected by profound changes.

Over the last two decades, European countries have had to face various challenges such as [2]:

- rapid international economic integration - a fact which is well known by the term "globalization";

- segmentation of the labor market, i.e. the dual existence of the protected and least protected sectors;

- accelerated development and implementation of new technologies;

- the decrease in working -age population due to the aging trend of the whole population

The labor market in Romania features certain instability that corresponds to the general coordinates of any country in transition.

\footnotetext{
1 “Dunarea de Jos” University, Galati, Romania, ramona.calinica@ugal.ro

https://doi.org/10.18662/lumproc.rce2017.1.32

Corresponding Author: Ramona Mariana CĂLINICA

Selection and peer-review under responsibility of the Organizing Committee of the conference
} 


\section{The Effects of Globalization on the Romanian Labor Market}

The main indicators that characterize Romania's labor market, namely the rate of activity, the employment rate and the unemployment rate, will be further analyzed. In order to analyze the impact of globalization on the labor market, the data from the internval 2003-2015 provided by the National Institute of Statistics database will be taken into account.

Table 1. Employment rate in Romania in the period 2003-2009 (\%)

\begin{tabular}{|c|r|r|r|r|r|r|r|}
\cline { 2 - 8 } \multicolumn{1}{c|}{} & $\mathbf{2 0 0 3}$ & $\mathbf{2 0 0 4}$ & $\mathbf{2 0 0 5}$ & $\mathbf{2 0 0 6}$ & $\mathbf{2 0 0 7}$ & $\mathbf{2 0 0 8}$ & $\mathbf{2 0 0 9}$ \\
\hline Total & 54,8 & 56,2 & 55,7 & 56,9 & 57,1 & 56,9 & 55,7 \\
\hline Men & 62,5 & 64,4 & 64,4 & 65,9 & 66,4 & 66,9 & 65,6 \\
\hline Women & 47,6 & 48,5 & 47,7 & 48,6 & 48,4 & 47,5 & 46,6 \\
\hline
\end{tabular}

Source: National Institute of Statistics database

Following the year-to-year evolution and comparing the data, it is noted that the highest labor force activity rate in the analyzed period was reached in 2007 (57.1\%), the year when Romania joined the European Union, and the lowest level was reached in 2011 (54.1\%).

Analyzing the rate of activity according to gender, it can be seen that among men it oscillated between $62 \%$ and $67 \%$, while for women it did not exceed the level of $49 \%$ over the entire period considered. At the same time, the highest rate was registered among the men in $2008(66.9 \%)$, and in the case of women in 2006 (48.6\%).

The rate of activity is an important indicator in the economy of each country, and in the case of Romania this is quite low which indicates certain problems.

Thus, "the material support for an increasingly aging population increasingly brings to question the degree of participation of this population to the economic activity, both in total and by gender and age groups. This is because the idea of an extended active life and social protection by occupation becomes more and more emphasized. [3]

Table 2. Employment rate in Romania in the period 2010-2015 (\%)

\begin{tabular}{|c|r|r|r|r|r|r|}
\cline { 2 - 7 } \multicolumn{1}{c|}{} & $\mathbf{2 0 1 0}$ & $\mathbf{2 0 1 1}$ & $\mathbf{2 0 1 2}$ & $\mathbf{2 0 1 3}$ & $\mathbf{2 0 1 4}$ & $\mathbf{2 0 1 5}$ \\
\hline Total & 54,9 & 54,1 & 54,6 & 54,5 & 54,9 & 54,5 \\
\hline Men & 64,2 & 62,7 & 63,6 & 63,7 & 64,2 & 64,5 \\
\hline Women & 46,2 & 46,1 & 46,2 & 46 & 46,2 & 45,2 \\
\hline
\end{tabular}

Source: National Institute of Statistics database 
Table 3. Variation of the employment rate

\begin{tabular}{|c|c|c|}
\cline { 2 - 3 } \multicolumn{1}{c|}{} & $\begin{array}{c}\text { Absolute variation } \\
\mathbf{2 0 1 5 / 2 0 0 3}\end{array}$ & $\begin{array}{c}\text { Relative variation (\%) } \\
\mathbf{2 0 1 5} / \mathbf{2 0 0 3}\end{array}$ \\
\hline Total & $-0,30$ & $-0,55$ \\
\hline Men & $+2,00$ & $+3,20$ \\
\hline Women & $-2,40$ & $-5,04$ \\
\hline
\end{tabular}

Source: National Institute of Statistics database

Analyzing the variation of the activity rate in the table above, it is noted that its size in total in 2015 compared to 2003 is lower by $0.3 \%$, which means in relative value 0.55 percentage points. Generally, this is an insignificant decrease. The decrease in the rate of activity among women by $2.4 \%$ and 5.04 percentage points respectively contributed negatively to this decrease, and in the positive sense the increase in the male activity rate by $2 \%$ and by 3.20 percentage points respectively.

Table 4. Employment rate in Romania in the period 2003-2009 (\%)

\begin{tabular}{|c|r|r|r|r|r|r|r|}
\hline & $\mathbf{2 0 0 3}$ & $\mathbf{2 0 0 4}$ & $\mathbf{2 0 0 5}$ & $\mathbf{2 0 0 6}$ & $\mathbf{2 0 0 7}$ & $\mathbf{2 0 0 8}$ & $\mathbf{2 0 0 9}$ \\
\hline Total & 51 & 51,7 & 51,8 & 52,8 & 53,5 & 53,7 & 52,1 \\
\hline Men & 57,9 & 58,7 & 59,4 & 60,6 & 61,6 & 62,5 & 60,7 \\
\hline Women & 44,6 & 45,2 & 44,7 & 45,7 & 45,9 & 45,4 & 44 \\
\hline
\end{tabular}

Source: National Institute of Statistics database

Regarding the Employment Rate (Table 5), it can be noticed that after the significant increase in the period 2003-2008, respectively from $51 \%$ to $53.7 \%$, it followed a decrease of its level during 2009-2011, because of the intense effects of the economic and financial crisis. Thus, the year 2011 marked the lowest recorded level of the employment rate in Romania $(50.2 \%)$, of the whole analyzed period. In the next years the evolution of this indicator was oscillating, with a slight revival of its value, but 2015 was again marked by the reduction of the occupancy rate to $50.8 \%$.

Table 5. Employment rate in Romania in the period 2010-2015 (\%)

\begin{tabular}{|c|c|c|c|c|c|c|}
\hline & $\mathbf{2 0 1 0}$ & $\mathbf{2 0 1 1}$ & $\mathbf{2 0 1 2}$ & $\mathbf{2 0 1 3}$ & $\mathbf{2 0 1 4}$ & $\mathbf{2 0 1 5}$ \\
\hline Total & 51,1 & 50,2 & 50,9 & 50,7 & 51,1 & 50,8 \\
\hline Men & 59,4 & 57,9 & 58,9 & 58,8 & 59,5 & 59,6 \\
\hline Women & 43,3 & 43,1 & 43,4 & 43,1 & 43,3 & 42,6 \\
\hline
\end{tabular}

Source: National Institute of Statistics database 
Analyzing the employment rate by gender, it can be noted that throughout the analyzed period, this is lower among women than in men. In both cases this indicator had an oscillating evolution, with increases and decreases from year to year. There is a significant decrease in the period 2009-2011, both in men and women, reaching $57.9 \%$ and $43.1 \%$ respectively in 2011, while in 2008 there were net higher values of $62.5 \%$ and $45.4 \%$ respectively. According to the data in the table below, the total employment rate decreased by $0.20 \%$ between 2003 and 2015 or 0.39 percentage points. The employment rate for males increased by $1.70 \%$ or by 2.94 percentage points, while for women it fell by $2 \%$ or by 4.48 percentage points.

Table 6. Variation of the employment rate

\begin{tabular}{|c|r|r|}
\cline { 2 - 3 } \multicolumn{1}{c|}{} & $\begin{array}{c}\text { Absolute variation (\%) } \\
\mathbf{2 0 1 5 / 2 0 0 3}\end{array}$ & $\begin{array}{c}\text { Relative variation } \\
\mathbf{( \% )} \mathbf{2 0 1 5 / 2 0 0 3}\end{array}$ \\
\hline Total & $-0,20$ & $-0,39$ \\
\hline Men & $+1,70$ & $+2,94$ \\
\hline Women & $-2,00$ & $-4,48$ \\
\hline
\end{tabular}

Source: National Institute of Statistics database

The functioning of the labor market in Romania requires improvements, given that the employment rate is decreasing, reaching only $50.8 \%$ in 2015. Thus, Romania is still far from achieving the European desideratum on employment as established by the Europe 2020 strategy, namely the $70 \%$ employment rate set for 2020 . This strategy aims to make Europe smart, sustainable and inclusive while searching for proper means to create new jobs. [5]

Table 7. Unemployment rate in Romania in period 2003-2009 (\%)

\begin{tabular}{|c|r|r|r|r|r|r|r|}
\hline & $\mathbf{2 0 0 3}$ & $\mathbf{2 0 0 4}$ & $\mathbf{2 0 0 5}$ & $\mathbf{2 0 0 6}$ & $\mathbf{2 0 0 7}$ & $\mathbf{2 0 0 8}$ & $\mathbf{2 0 0 9}$ \\
\hline Total & 7 & 8 & 7,1 & 7,2 & 6,4 & 5,6 & 6,3 \\
\hline Bărbați & 7,5 & 8,9 & 7,7 & 8,1 & 7,2 & 6,5 & 7,3 \\
\hline Femei & 6,4 & 6,8 & 6,4 & 6 & 5,2 & 4,4 & 5,4 \\
\hline
\end{tabular}

Source: National Institute of Statistics database

The unemployment rate is an important factor to consider when taking economic or social protection measures. The lowest unemployment rate in the analyzed period (Table 7) is $6.4 \%$, recorded in 2007, the year when Romania joined the European Union. The highest value of this indicator was achieved in 2004, namely $8 \%$. This year, both among men and among women, the unemployment rate has reached a peak. In the interval 2009-2011, this indicator experienced an unfavorable evolution because of the effects of the global crisis. Thus, if in 2008 the unemployment rate was 
$5.6 \%$, in 2011 it reached the level of $7.2 \%$. Over the period ahead, with the exception of 2013, there was a stabilization of around $6.8 \%$.

Table 8. Unemployment rate in Romania in period 2010-2015 (\%)

\begin{tabular}{|c|r|r|r|r|r|r|}
\cline { 2 - 7 } \multicolumn{1}{c|}{} & \multicolumn{1}{c|}{$\begin{array}{c}\text { Anul } \\
\mathbf{2 0 1 0}\end{array}$} & $\begin{array}{c}\text { Anul } \\
\mathbf{2 0 1 1}\end{array}$ & $\begin{array}{c}\text { Anul } \\
\mathbf{2 0 1 2}\end{array}$ & $\begin{array}{c}\text { Anul } \\
\mathbf{2 0 1 3}\end{array}$ & $\begin{array}{c}\text { Anul } \\
\mathbf{2 0 1 4}\end{array}$ & $\begin{array}{c}\text { Anul } \\
\mathbf{2 0 1 5}\end{array}$ \\
\hline Total & 7 & 7,2 & 6,8 & 7,1 & 6,8 & 6,8 \\
\hline Men & 7,6 & 7,7 & 7,4 & 7,7 & 7,3 & 7,5 \\
\hline Women & 6,2 & 6,5 & 6,1 & 6,3 & 6,1 & 5,8 \\
\hline
\end{tabular}

Source: National Institute of Statistics database

In 2015, Romania had an unemployment rate of $6.8 \%$ for a population of 20 million people, which was not a very high percentage.

Looking at Table 9, the overall unemployment rate decreased by $0.2 \%$ in 2015 compared to 2003 . The deviation unemployment rate among men is 0 , reaching the same level in 2015, but for women, the difference is considerable increasing up to $0.6 \%$ in 2015 compared to 2003 .

Table 9. Variation of the unemployment rate

\begin{tabular}{|c|c|c|}
\hline & $\begin{array}{c}\text { Absolute variation } \% \\
2015 / 2003\end{array}$ & $\begin{array}{c}\text { Relative variation }(\%) \\
2015 / 2003\end{array}$ \\
\hline Total & $-0,2$ & $-2,86$ \\
\hline Men & 0 & 0,00 \\
\hline Women & $-0,6$ & $-9,38$ \\
\hline
\end{tabular}

Source: National Institute of Statistics database

The chart below shows the dynamics of the unemployment rate according to gender.

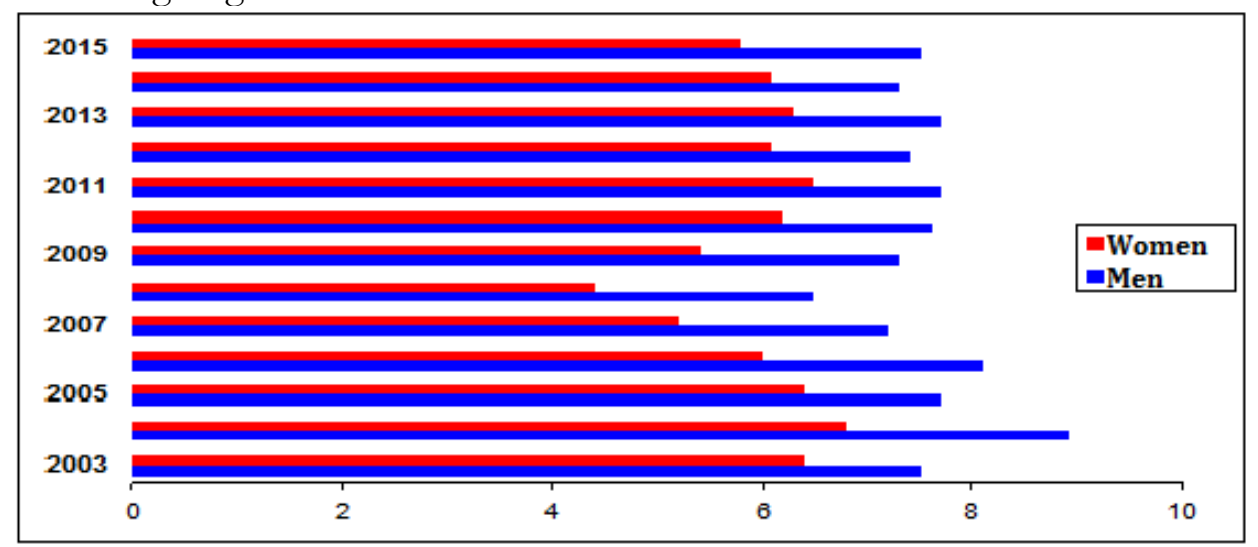

Source: National Institute of Statistics database

Figure 1. Unemployment rate in Romania in period 2003-2015 
The global crisis has led to a situation where many people have lost their jobs, and another category of people has been reluctant to look for a job, this situation taking them out of both employees and unemployed category, that is why unemployment does not register alarming values in statistics, especially when many people are working in subsistence farming.

The situation of emigrants from Romania during the period 20022012 will be further studied.

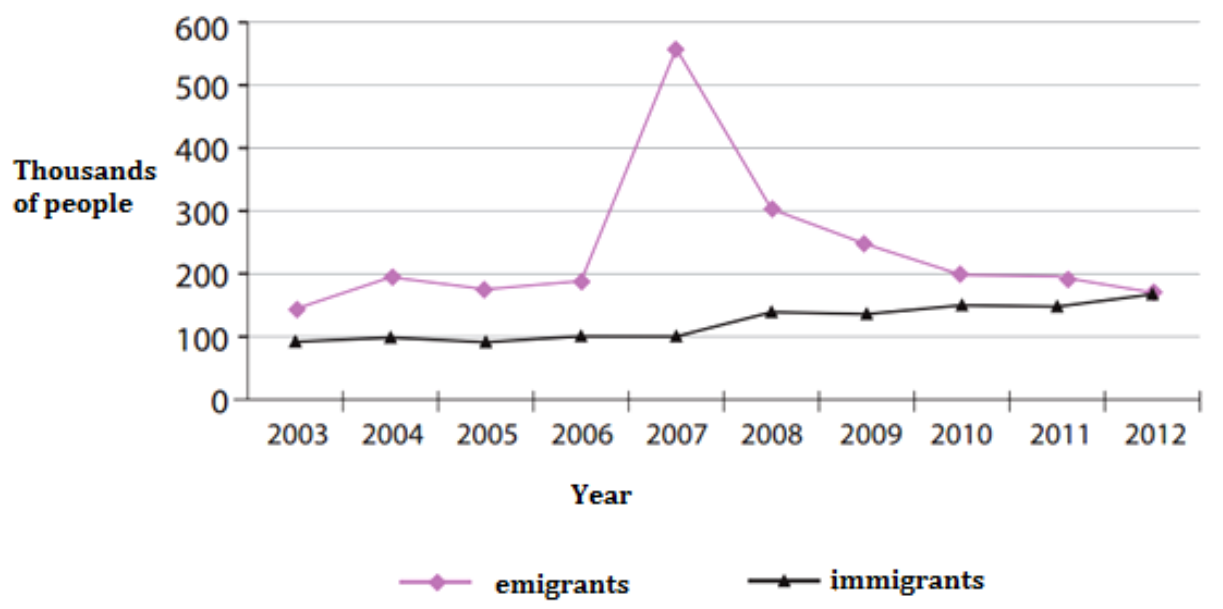

Source: National Institute of Statistics database

Figure 2. The flow of emigrants and immigrants during the period 2003-2012

Analyzing the figure above, it can be seen that the migration in Romania experienced during the analyzed period increases and decreases in terms of the number of migrants. Thus, in 2007, the year when Romania joined the European Union, it was reached the highest level of emigration, almost 600 thousand people. Then, since 2008, there has been a significant decrease. In 2012 the number of emigrants was below 200 thousand. From the perspective of immigrants, the variations are not so high, ranging between 100,000 and 200,000 immigrants in the period considered. Until adhesion to the European Union, the number of immigrants was approximately 100,000, after which an increase in the number of immigrants has occurred since 2007, but it did not exceed the limit of the aforementioned interval. In 2012 there was a balancing of the number of immigrants and emigrants, which is virtually the same. Regarding the number of emigrants according to age and gender, it is noted in the figure below that the highest number in 2002 is reached by men aged 24 (almost 30 thousand) and women aged 20 (just over 20 thousand). In 2012 there is a 
significant increase in emigrants: maximum number of men aged 32-33 ( 45 thousand) and women aged 24 ( 40 thousand).

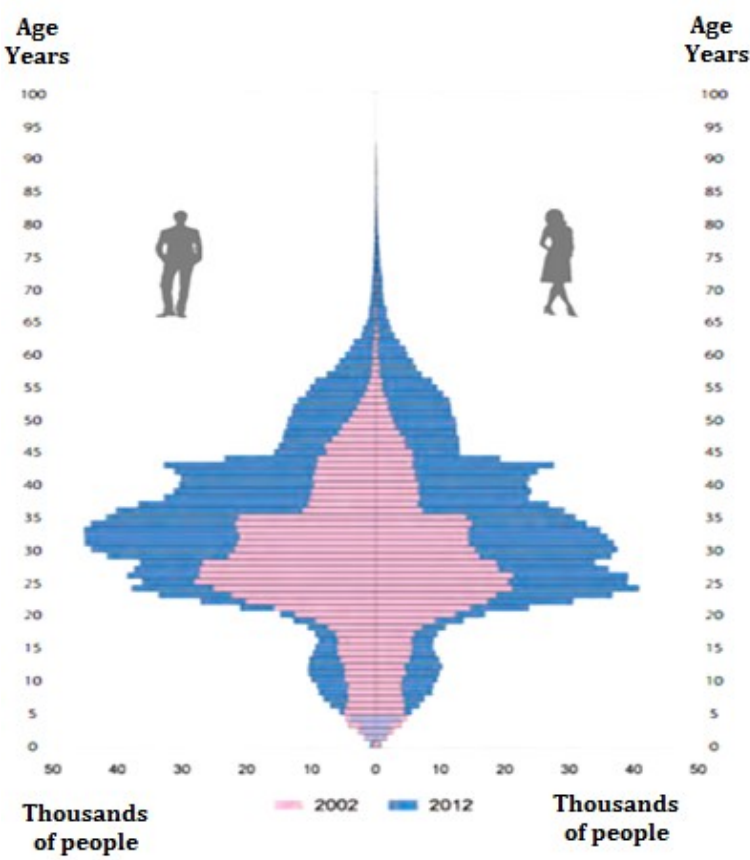

Source: National Institute of Statistics database

Figure 3. Number of emigrants according to age and gender on January 1 , 2002 and 2012



Source: National Institute of Statistics database

Figure 4. Structure of emigrants on January 1, 2002 and 2012 according to age

Analyzing the number of emigrants as a percentage of the total, it is noticed that most emigrants in 2002 are those aged 25-64 (68\%), and in 2012 their number increased by $8 \%$. The fewest emigrants are children, with a 
share of $10 \%$ in 2002 and $8 \%$ in 2012. In 2012, emigrants aged 65+ are also present in $1 \%$.

Thus, in 2012, according to the National Institute of Statistics, the Romanian emigrants have chosen the following countries of destination [6]:

- Italy- $40 \%$

- Spain-34\%

- Germany-7\%

- United Kingdom-4\%

- Hungary-3\%

- Other countries - 6\%

In the period 2008-2012, most of the emigrants chose Italy, Spain and Germany. Thus, in 2012, 40\% of Romanian emigrants were in Italy, $34 \%$ in Spain, and 7\% in Germany.

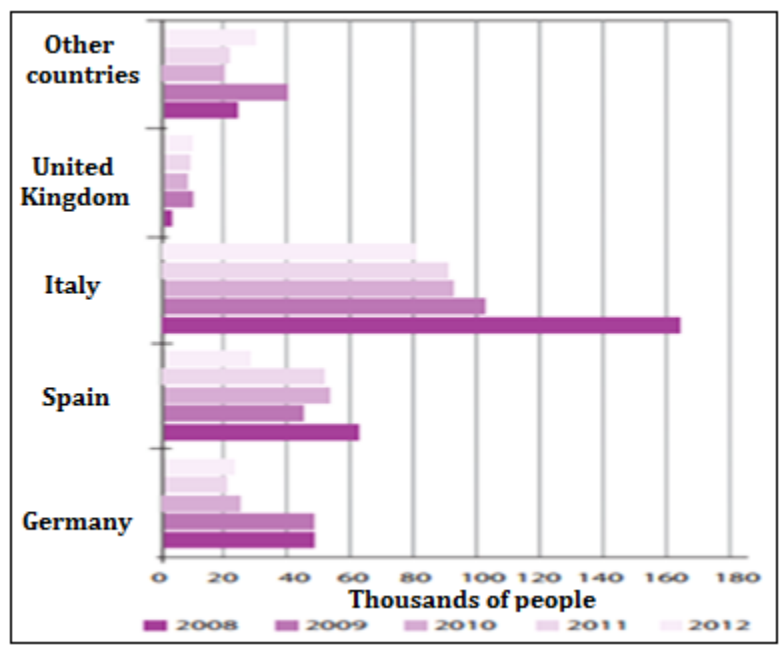

Source: National Institute of Statistics database

Figure 5. Emigrants according to main destination countries in period 2008-2012

In order for migration from Romania to be a factor of development of the national economy it is necessary to foster related politics able to balance the use of labor on domestic markets and migrations of labor. The flow of population from Romania to the European Union is different in terms of the period of transition, namely pre-accession, post-accession and that of free circulation of workers in 2014. Politics are different on behalf of Romania as origin country and the destination countries. An important 
factor should be considered is migration to Romania which will become the Eastern border of the European Union [4].

\section{Conclusions}

Globalization is a major phenomenon within the world economy in general, causing major changes in the various national economies. From the point of view of the impact of globalization on the labor market, it can be argued that the integration of workers from emerging countries and developing countries into the global labor market represents an advantage for the workers concerned and generates important benefits for the advanced economies. In the case of Romania, especially after its joining the European Union, labor migration has experienced a strong dynamics, driven by the opportunities offered by the external environment. Thus, there has been an impressive wave of emigration to countries like Italy, Spain and Germany.

The rate of activity/employment is an important indicator in the economy of each country, and in the case of Romania it can be seen a low level, suggesting certain problems in terms of its decrease, an important aspect being the aging of the active population, thus highlighting more and more the idea of an active life as long as possible and of social protection by employment.

The functioning of the labor market in Romania requires improvements, given that the employment rate is declining, Romania being still far from achieving the European employment target as set by the Europe 2020 Strategy.

\section{References}

[1]. Barbu V, Cernat C. Impactul Globalizării asupra Pieței Forței de Muncă. EIRP Proceedings. 2011 Jan 8;1. Available from:

http://www.proceedings.univdanubius.ro/index.php/eirp/article/viewFile/ $1168 / 1084$

[2]. Blaga E. Mobiliatea forței de mună: consecințe pentru piața muncii românească. Asocația Zamolxe [Internet]. Slatina: 2009 [cited 2017 May 02]. Available from: http://asociatia-zamolxe.ro/node/64

[3]. Simion M. Rata de activitate economică a populației româniei. Nivel şi deziderate. Revista Română de Sociologie [Internet]. Bucuresti: 2012 [cited 2017 Dec 15]; 1(2): 68. Available from: http://www.revistadesociologie.ro/pdf-uri/nr.1-2-2012/04-MSimion.pdf

[4]. Moldovanu D. Economia Politică. Bucureşti: ARC; 2001. 96 p. 
[5]. Ministerul muncii, familiei, protectiei sociale si persoanelor varstnice. Strategia Națională pentru Ocupare a Forței de Muncă 2014 - 2020 Anexa 1. Bucureşti: ANOFM; 2014 [cited 2017 May 02]. Available from: http://www.mmuncii.ro/j33/images/Documente/Munca/2014DOES/2014-01-31_Anexa1_Strategia_de_Ocupare.pdf

[6]. Institutul National de Statistica [Internet]. Bucureşti: INSSE; 2016 [cited 201701 May]. Available from: http://www.insse.ro/cms/ro/search/node/forta $\% 20 \mathrm{de} \% 20$ munca 